\title{
The Style of Customer Decision Making in the Bugis Community in Jambi
}

\author{
Kurniati Karim ${ }^{\mathrm{a}, *}$, Ahmad Hosen ${ }^{\mathrm{a}}$ \\ ${ }^{a}$ Department of Management, Sekolah Tinggi Ilmu Ekonomi Sakti Alam, Kerinci, Indonesia
}

\begin{abstract}
The Bugis tribe is one of the tribes that resides in South Sulawesi Province. This tribe is known to be very rational in acting and is always based on the teachings of the ancestors in the form of "Mappesona ri Dewata Seuwae" which means based on God Almighty. The Bugis tribe is known as an accomplished seaman, so they inhabit all provinces in Indonesia, including in Jambi Province. By inhabiting the Jambi area, the influence of the local culture will certainly affect the behavior of someone who resides in the area. Regarding this, the purpose of this research is to find out whether the decision making model of the Bugis people who live in Jambi still consider the Bugis cultural value when making product purchase decisions. The research sample consisted of 106 people, data were collected through questionnaires, and then analyzed descriptively quantitatively by calculating the index number values. The analysis shows that although the Bugis people have settled in Jambi, Sumatra, the product purchasing decision model is based on the value of the faith taught by the Bugis ancestors.
\end{abstract}

Keywords: customer decision, bugis culture, bugis overseas, Jambi

\section{INTRODUCTION}

When making a decision to buy a product, consumers are also influenced by culture, where one of the cultural indicators is religion (Kotler and Keller, 2012). This is in accordance with Hofstade's opinion, quoted by Karim and Tajibu (2019), however, Hofstede (1980), stressed that the national culture of a country has a difference that is Western society is individualistic, and society in the East is more collectivism.

This can also be seen in the Bugis community in South $\mathrm{Su}-$ lawesi, who in their behavior highly uphold the teachings of their ancestors, where the activities to be carried out always require prior consideration from their parents or traditional leaders. The religious teachings and teachings of the ancestors taught what his followers should and should not do. From these teachings we obtain the values of faith that guide our daily behavior. Asih (2015), citing Taylor's opinion, 1975, stated that religion is the most fundamental foundation of culture that influences the habits, attitudes, and values of consumers. For a Muslim, religiosity can be known from the extent of knowledge, belief, implementation and appreciation of the religion of Islam (Nashori, 2004a). Martin Fishbein (2015) stated that based on

\footnotetext{
* Author in correspondence,

Email address: atiekkarim299@gmail .com (Kurniati Karim)
}

ISSN: 2549-3221 (Print) 2549-323X (Online)

DOI: $10.26487 /$ hebr.v4i2.2446 theory of reasoned action, assumes that beliefs can represent information that individuals have about objects, so that there is a very close religious relationship and attitude.

Religious values directly affect the behavior of followers, so it is assumed that the values of faith from the culture adopted also affect the choice of products to be consumed. For example, the fasting tradition practiced by Muslim communities will determine what food and clothing to consume, as well as other religions. Kasnaeny (2016) has examined the relationship between purchasing decisions with religious values in the Bugis community in the city of Makassar and found that the value of religiosity is crucial in purchasing products. The main thing to do before buying a product is to pay attention to halal aspects, dose accuracy, and origin of the product. Delener (1994) states that religion has a strong influence on people's beliefs, personal, identity and value systems, and can have implications for consumption.

If examined more broadly, studies on the relationship of religion to the community purchasing decision model have not been much studied. The lack of religious-based studies, according to Solomon et al. (2007) due to culture (religion / norms / morals) is taboo to be discussed. Thus, further proof is needed to examine the relationship with consumer purchasing decisions, but looking at the conditions of the Bugis overseas who settled in Jambi Province.

Thus, this research will continue the research from Kasnaeny (2016) focusing on studying the buying decision-making behavior of Bugis consumers overseas, especially in Jambi. The 
aim is to find out whether religious values are taken into consideration by overseas Bugis communities in purchasing products. In addition, there are different opinions from Astogini et al. (2011) who say that one's level of faith does not have a significant influence on purchasing decisions for halal products, resulting in a research gap due to differences in results.

Based on these differences, there is a gap for more in-depth research, by examining the consumer objects of the Bugis community in the Jambi area. Jambi was chosen because in this province, many people from the South Sulawesi Province were residing, mainly Bugis ethnic groups.

Conflicts between the Bugis and Makassar kingdoms and conflicts between fellow Bugis kingdoms in the 16th, 17th, 18th and 19th centuries, caused unrest in South Sulawesi. This caused many Bugis to migrate, especially those living in coastal areas. In addition, the habit of wandering is also driven by the desire to feel independence. Bugis people feel happy if they are free, including freedom to migrate.

According to Wikipedia.com, the Bugis people began to migrate to Sumatra, including to Jambi, when their territory was colonized by the Dutch. Bugis residents gradually left South Sulawesi around the 1950s, aiming to find a safer area. Bugis communities in Jambi Province mostly live in the east coast of Jambi Province, namely in the Regency of Tanjung Jabung Barat (Kuala Tungkal, Pangkal Duri) and in the District of Tanjung Jabung Timur (Mendahara, Kampung Laut, Tanjung Solok, Muara Sabak, Alang Alang, Simbur Naik, Lambur, Pemusiran, Nipah Panjang) and settling on land such as in Jambi City and mostly in Tangkit Baru Village, Muaro Jambi Regency. In addition to Jambi Province, Bugis residents also spread in neighboring areas, namely in Indragiri Hilir Regency, Riau Province (Kijang Island, Terab River, Keritang, Kotabaru Reteh, Sanglar, Pebenaan, Benteng, Kuala Enok, Tanah Merah, Tembilahan, Sungai Guntung, Pulau Burung).

\section{LITERATURE REVIEW}

\subsection{Consumer behavior}

Consumer behavior is an activity to get, consume, and spend products. However, according to Blackwell et al. (2001), these activities did not stop there, but also included a decision process that preceded and followed this action. While the opinions of Solomon et al. (2007) and Ahmed and Dahari (2007), Philip Kotler (1998) and Schiffman Leon G (2010) state that buying behavior the consumer is the buying behavior of the end consumer, individual and household and is a study of how individuals make decisions regarding consumption, which includes what they buy, why they buy, where they make a purchase and how often they buy and how often they use it. Tauber (1972) states that there have been many definitions of the dimensions of purchasing behavior, but very few explain the determinants in determining consumption and consumer spending behavior.

One that affects consumers is their culture, subculture and social class, where religion is part of a subculture. This is based on the statement of Kotler and Keller (2012) that consumer buying behavior is strongly influenced by culture, subculture, and social class.

\subsection{Culture, Religiosity and Consumption}

Purchasing behavior is also influenced by culture Kotler and Keller (2012). Each culture consists of smaller subcultures that include nationalities, religions, racial groups, and geographical areas, and more specific socialization as identification for its members. Religion teaches what its followers must and should not do. This teaching produces the values of faith that guide in acting or behaving. Religiosity (faith) is defined as the extent of knowledge, how strong beliefs, how the implementation of worship and rules, and how deep the appreciation of the religion it adheres to. For a Muslim, religiosity can be known from the extent of knowledge, belief, implementation and appreciation of the religion of Islam (Nashori, 2004a).

Delener (1994) states that it was widely recognized that personality, beliefs, identity and value systems adopted by the community were strongly influenced by religion, and could have implications for consumption. For this reason, further proof is needed to examine its relationship with the buying decision making style. Based on the opinion of Astogini et al. (2011) quoted the statements of Glock and Stark (1965), there are five dimensions which are indicators of religiosity, i.e, (1) Ritual Dimensions; is an obligation to carry out one's traditions or habits based on their religion, (2) the ideological dimension; is a person's belief to accept things that are dogmatic (for example, belief in the existence of God, Angels, Satan, Heaven and Hell) based on his religion, (3) intellectual dimensions; namely the ability of a person related to knowledge, the ability to understand, and the ability to understand the teachings of his religion, accompanied by the willingness to carry out activities related to his religion, (4) dimensions of experience; measure how far a Muslim feels and experiences religious feelings and experiences. For example, the feeling of being close to Allah, the feelings of his prayers are often answered, a feeling of peace and happiness, to live, to be solemn when performing prayers, and other favors from Allah SWT, (5) dimensions of consequences, in this case related to one's willingness to commit to the teachings of his religion in daily life.

\subsection{Customer Decision Making Style}

Customer decision making is very important now compared to the past. Many advertisements, news both in electronic media, newspapers or direct mail, besides the diversity of product offerings, shopping centers means that there are many choices available to consumers and the decision to choose more difficult (Jeane et al., 2005). The emergence of technology that increasingly makes products look attractive, causes decision making to become more complex and complicated. Some categories of consumer behavior assume that all consumers shop using a certain approach in making purchasing decisions (Walsh et al., 2001). Consumer decision making style is an approach based on the orientation of the mental characteristics of consumers to make choices "Sproles, (1986a) sees this construction as" the basic personality of the consumer ", equivalent to the concept of personality in psychology.

Sprotles and Kendall (1986), citing some of the writings, the approach based on the type of consumer seeks to differentiate consumers in general based on their "type". Meanwhile, 
the psychographic approach identifies characteristics that are relevant to consumer behavior and leads to lifestyle levels or interest in certain types of products

The most powerful approach is based on consumer characteristics because its main focus is on mental orientation in consumer decision making. The cognitive and affective orientation of consumers is included in this approach, which assumes that the style of decision making can be determined based on the general orientation towards shopping and buying activities (Lysonski, 1996). Meanwhile, Bennett et al. (1977) and Hofstede (1980) state that individual values have been proven to be significantly influenced by national culture and shape the consumer's decision to make a purchase.

\section{METHODS}

This research is a quantitative descriptive study, which is to find out whether the value of religiosity of the Bugis culture is still considered in making product purchasing decisions in the Bugis community in Jambi. The sample in this study amounted to 106 people,obtained through snowball sampling techniques with consideration of the spread of the existence of people who come from the Bugis tribe of South Sulawesi in Jambi province. Data obtained through the distribution of questionnaires, which contain indicators of ritual dimensions, idiological dimensions, intellectual dimensions, experiential dimensions, and consequence dimensions (Astogini et al., 2011). The analysis used is descriptive analysis by calculating factor index values (Ferdinand, 2006).

\section{RESULTS AND DISCUSSION}

\subsection{Results}

Table 1 shows the characteristics of the respondents. Characteristics based on gender, showed male respondents numbered 59 people and women numbered 47 people. Based on age, most respondents were seen between the ages of 35 to 45 years, age over 45 years, amounting to 26 people, as well as the age range of 20 to 35 years. Meanwhile, respondents aged up to 20 years amounted to 9 people. Based on work, the majority of respondents were housewives by 23 people and entrepreneurs by 19 people. The education level of most respondents came from high school level, and the length of stay in Jambi was 20 years.

Table 1: Index Numbers

\begin{tabular}{lll}
\hline Variable Value Religiosity & Scale & Statement \\
\hline Ritual Dimension & 40,29 & Considerable \\
The ideological dimension & 40,05 & Considerable \\
Intellectual Dimension & 40,20 & Considerable \\
Experience Dimension & 40,01 & Considerable \\
Dimensions of Consequence & 40,27 & Considerable \\
\hline
\end{tabular}

Then the research instrument test is conducted, which is carried out to determine whether all indicators listed in the questionnaire are valid and reliable. Validity test is carried out based on the significant value obtained from correlation analysis, where if the significant value 0.05 then the research instrument is valid and can be continued to the next process. Likewise, a reliability test was carried out based on the Cronbach- $\alpha$ value, where if the acquisition value is greater than 0.60 then the research instrument has been reliable.

Validity test results show that all research indicators have a significant value below 0.05 , which means that all research indicators are valid and can be continued in the analysis. The overall indicators in the questionnaire proposed in the study are reliable, because they exceed the Cronbach- $\alpha$ value limit of 0.60 .

\section{Index Number Analysis}

Index number values are obtained based on the following formula:

$$
\frac{\sum_{i=1}^{n} F_{i} x_{i}}{n}
$$

where,

$F_{i}$ is the frequency of respondents who answered "n"

$x_{i}$ : observation value

The results of the values are then interpreted using a scale range with the Three Box Method, namely:

- 10 - 40 : not considered in decision making

- $40.01-70$ : consideration is enough in making decisions

- 70.01 - 100 : considered in decision making

The calculation results look as Table 1. From the calculation results it can be seen that the range of scales is at 4.01 to 7 , so it can be interpreted that the model of consumer decision making when purchasing products based on religious values. This can be seen from the statements of respondents who stated that they sufficiently consider the five dimensions of religious values.

\subsection{Discussion}

Looking at the responses of respondents regarding the decision making of a Bugis customer in purchasing a product, it is seen that the value of faith obtained from culture is sufficiently considered in deciding the choice of the desired product. The value of faith is the process of abstracting religious values both in the heart and in speech (Ma'zumi et al., 2017). Philip Kotler (1998) states that the behavior of purchasing decisions on products can be influenced by culture where the value of faith includes indicators of cultural variables.

Based on descriptive statistical values on the variable value of religiosity, shows that Bugis respondents have good faith values, although it appears that it does not $100 \%$ consider the values of faith that originate from their culture. This can happen because there has been a mixture of cultures between Bugis culture and Sumatran culture, even though they are both ethnic Melayu. A detailed description of the Bugis consumer decision making style in Jambi is as follows. 
1. Ritual dimension (X.1) has a Good response, seen from a scale value of 4.29. This means that the Bugis community in Jambi. The meaning is that the Bugis community in Jambi in making product purchase decisions still consider the value of religiosity (the value of faith) that comes from observance of religion and is an embodiment of religious worship taught by families about what can be bought and which should not be consumed.

2. Ideological dimension (X.2), the results of the questionnaire processing show are in the scale range value of 4.04. The interpretation is that when making a product purchase decision, the Bugis community in Jambi considers religious values derived from the teachings of Islam. The values considered are related to halal or haram in a product according to religious teachings.

3. Intellectual dimension (X.3) shows the results are on a scale value of 4.17 means that the intellectual dimension is also a consideration in the decision to purchase products in the Bugis community in Jambi. Intellectual Dimension means someone's ability to understand religious teachings and implement them in daily activities. Intellectual ability of a person will be able to be a tool to consider everything with logic but not against religious teachings.

4. Knowledge dimension (X.4), the results of data processing showed a scale value of 3.96. This value is the lowest among the 5 other indicators perceived by respondents. However, from this value it can be interpreted that the knowledge of respondents obtained from religious learning, is sufficiently considered in the product purchase decision. Consumers have knowledge about suitable products that are purchased according to religious teachings and products that may not be consumed or prohibited by religious teachings. Respondents know the reasons why a product can be consumed and why there are products that should not be consumed.

5. Indicator of consequences dimensions (X.5), this dimension is the final result or impact of an activity or act carried out. This impact can be positive or negative for yourself, others, activities, situations, or the environment. The scale value obtained for this indicator is 4.27 , which means that the consequence dimension is the consideration of respondents in making product purchase decisions.

Based on the research findings, the results of this study support the research conducted by Mustafa and Amjad (2011), and Kasnaeny (2016) that Bugis consumers consider religious values in making purchasing decisions.

\section{CONCLUSION}

Although they have lived in foreign countries for a long time, the Bugis people in Jambi still apply the values of religiosity taught by their ancestors in product purchasing decisions. It can be seen that there is a similarity in belief in religious values between the Bugis people who live in Sulawesi and the Bugis people in Jambi. Thus, even though consumers have gained experience with a new culture, the values of the ancestors remain a consideration in making product purchase decisions.

\section{References}

Ahmed, Zafar U.and Ghingold, M., Dahari, Z., 10 2007. Malaysian shopping mall behavior: an exploratory study. Asia Pacific Journal of Marketing and Logistics 19.

URL: http://gen.lib.rus.ec/scimag/index.php?s=10.1108/ 13555850710827841

DOI: $10.1108 / 13555850710827841$

Asih, D., 10 2015. Dimensi-dimensi Spiritualitas dan Religiusitas dalam intensi keperilakuan konsumen.

URL: https : //doi.org/10.13140/RG.2.1.3375.1765

Astogini, D., Wahyudin, Wulandari, S. Z., 03 2011. Aspek Religiusitas dalam Keputusan Pembelian Produk Halal (Studi tentang labelisasi halal pada produk makanan dan minuman kemasan). JEBA 13 (1), 1-8.

Bennett, P. D., Ward, S., Kassarjian, H. H., 1977. Consumer Behavior. PrenticeHall.

Blackwell, R. D., Miniard, P. W., Engel, J. F., 2001. Consumer Behavior. Harcourt College Publishers.

Delener, N., 05 1994. Religious Contrasts in Consumer Decision Behaviour Patterns: Their Dimensions and Marketing Implications. European Journal of Marketing 28. DOI: $10.1108 / 03090569410062023$

Ferdinand, A., 2006. Metode Penelitian Manajemen, 2nd Edición. Universitas Diponegoro.

Glock, C., Stark, R., 1965. Religion and society in tension. Rand McNally, chicago.

Hofstede, G., 1980. Motivation, leadership, and organization: Do American theories apply abroad? Organizational Dynamics 9 (1), $42-63$.

URL: http://www.sciencedirect.com/science/article/pii/ 0090261680900133

DOI: https ://doi.org/10.1016/0090-2616(80)90013-3

Jeane, H., Chae, J., Chung, Y., 01 2005. Consumer Decision-Making Styles: Comparison Between United States and Korean Young Consumers. Journal of Consumer Affairs - J CONSUM AFF 26, 146-158. URL: https : //doi.org/10.1111/j.1745-6606.1992.tb00020.x

Karim, K., Tajibu, M., 2019. Tradisi Mappassili sebagai Salah Satu Penentu Kepuasan Konsumen Bugis Pasca Pembelian Produk di Kota Makassar. BISMA: Jurnal Bisnis dan Manajemen 13 (1), 19-26.

URL: https://jurnal.unej.ac.id/index.php/BISMA/article/ view/8817

DOI: $10.19184 /$ bisma.v13i1.8817

Kasnaeny, K., 2016. Customer decision making style, based on bugis -makassar culture in indonesia. International Journal of Business and Management Invention 5 (3), 1-6.

URL: https://www.ijbmi.org/papers/Vol(5)3/Version-2/ A503020106.pdf

Kotler, P., Keller, K. L., 2012. Marketing Management, 14th Edición. Prentice Hall.

Lysonski, Steven; Durvasula, S. Z. Y., 12 1996. Consumer decision-making styles: a multi-country investigation. European Journal of Marketing 30. URL: http://gen.lib.rus.ec/scimag/index.php?s=10.1108/ 03090569610153273 DOI: $10.1108 / 03090569610153273$

Martin Fishbein, I. A., 2015. Predicting and Changing Behavior: The Reasoned Action Approach. Psychology Press.

Ma'zumi, M., Taswiyah, T., Najmudin, N., 12 2017. Pengaruh religiusitas terhadap perilaku ekonomi masyarakat pasar tradisional. Alqalam 34 (2), 277300.

DOI: $10.32678 /$ alqalam.v34i2.791

Mustafa, L., Amjad, S., 12 2011. Emotional intelligence determining work attitudes and outcomes of university teachers: Evidence from pakistan. European Journal of Marketing 2.

Nashori, F., 01 2004a. Menjadi manusia kreatif: Ketua umum asosiasi psikologi islami. Humanitas: Indonesian Psychologycal Journal 1. 
Philip Kotler, Gary Armstrong, J. S. V. W., 1998. Principles of Marketing: European Edition, 2nd Edición. Financial Times/ Prentice Hall.

Schiffman Leon G, Leslie Lazar Kanuk, J. W., 2010. Consumer Behavior, 10th Edición. Pearson Prentice Hal.

Solomon, M., Bamossy, G.and Askegaard, S., Hogg, M. K., 2007. Consumer behaviour: A european perspective. Pharmacy world science: PWS 29. URL: https://doi .org/10.1007/s11096-005-3797-z

Sprotles, G. B., Kendall, E. L., 12 1986. A methodology for profiling consumers' decision-making styles. Journal of Consumer Affairs 20.

URL: http://gen.lib.rus.ec/scimag/index.php?s=10.1111/j. 1745-6606.1986.tb00382.x

DOI: $10.1111 / j .1745-6606.1986 . t b 00382 \cdot x$

Tauber, E., 1972. Marketing notes and communications: Why do people shop? Journal of Marketing 36 (4), 46-49.

URL: https ://doi.org/10.1177/002224297203600409

DOI: $10.1177 / 002224297203600409$

Walsh, G., Mitchell, V.-W., Hennig-Thurau, T., 06 2001. German consumer decision-making styles. Journal of Consumer Affairs 35, 73 - 95. DOI: $10.1111 / j .1745-6606.2001 . t b 00103 . x$ 